\title{
Spatial Cadmium Distribution in the Charente Watershed and Potential Risk Assessment for the Marennes Oleron Bay (Southwest France)
}

\author{
Coynel Alexandra, Khoury Alaa, Dutruch Lionel, \\ Blanc Gérard, Bossy Cécile, Derriennic Hervé and Schäfer Jörg \\ University of Bordeaux, EPOC, UMR 5805, Talence
}

France

\section{Introduction}

In recent years, high levels of pollutants in coastal ocean waters and in the marine food chain have been attributed to inputs either via the atmosphere (Nriagu, 1989) or by direct inputs from rivers and estuaries (e.g. Millward et al., 1996; Baeyens et al., 1997; Chiffoleau et al., 1999). In fact, rivers are considered as a major pathway for the organic and inorganic contaminant transfers from the continent to the ocean, especially during flood events (e.g. Coynel et al., 2007).

The Marennes Oleron Bay (MOB) is the first oyster-producing area in France providing nearly half of the oysters commercialised (Goulletquer \& Héral, 1997; Soletchnik et al., 1999, 2002; Bry \& Hoflack, 2004). The MOB and its biological compartments are subject to chronic pollution by some metals, especially $\mathrm{Cd}$, representing a potential risk for shellfish cultivation (Pigeot et al., 2006; Strady et al., 2011). The latest estimates suggest that legal restrictions of oyster production in the MOB would result in a shortfall of between $50 \%$ and $70 \%$ of oysters on the market in the next years. Given that oyster is one of the top ten seafoods consumed in France, the economic consequences would be catastrophic for this region.

The Gironde Estuary, located $\sim 30 \mathrm{~km}$ southward of the MOB, is affected by historic metal (e.g. Cd, Zn, Hg, Ag; Blanc et al., 1999; Schäfer et al., 2006; Castelle et al., 2009; Larrose et al., 2010; Lanceleur et al., 2011) contamination due to former $\mathrm{Zn}$ ore treatment in the industrial Decazeville basin, that was stopped after a major pollution accident in 1986. In this watershed drained by the Riou Mort River, anthropogenic contributions to particulate element fluxes were estimated to $\sim 90-95 \%$ for $\mathrm{Cd}, \mathrm{Zn}$ and $\mathrm{Hg}$ (Coynel et al., 2009). Despite decreasing $\mathrm{Cd}$ emissions in the Decazeville area due to ongoing remediation efforts since the early 1990s, the Lot-Garonne River system still contributes up to $80 \%$ to the annual Cd gross fluxes into the Gironde Estuary (Schäfer et al., 2002; Audry et al., 2004). Additionally, intensive agriculture and ongoing urbanization also considerably contribute to metal (e.g. $\mathrm{Zn}, \mathrm{Cu}, \mathrm{Ag}$ ) gross fluxes into the Gironde Estuary (e.g. Masson et al., 2006; Lanceleur et al., 2011). In contrast to the well-studied Garonne-Gironde system, the Charente fluvial- 
estuarine system remains poorly studied in spite of its great hydrological influence on the MOB. The Charente River is the major river discharging directly into the MOB. During summer, $90 \%$ of the freshwater inputs into the Bay come from the Charente River (RavailLegrand, 1993), which drains an area of 10,549 $\mathrm{km}^{2}$ dominated by farming (Bry \& Hoflack, 2004). Only few studies have previously assessed the importance of the Charente Estuary to the overall metal contamination of the MOB (Gonzalez et al., 1991; Boutier et al., 2000; Dabrin, 2009). Recently, Dabrin (2009) showed that dissolved and particulate Cd concentrations the outlet of the Charente watershed, i.e. at the entry of the Charente Estuary were similar to those in the Garonne River and contributed up to $60 \%$ to total Cd inputs into the MOB, highlighting the need to precisely identify the origin(s).

In this context, the objective of this study is to (i) characterize the Cd content in water $(<0.2 \mu \mathrm{m}$; dissolved phase) and in particles (SPM and stream sediments) exported by the Charente sub-watersheds; (ii) assess their level of contamination by comparison with world references and ecotoxicological indices and (iii) identify point sources and/or diffuse sources in the Charente watershed. This first assessment of the sub-watershed contributions to the fluvial $\mathrm{Cd}$ export is essential to the control and reduction of $\mathrm{Cd}$ contamination in oysters, i.e. to successful environmental management in this vulnerable region.

\section{Presentation of the study area}

The Charente watershed (surface area $=10,549 \mathrm{~km}^{2} ; \sim 500,000$ inhabitants) is surrounded by the Massif Central to the East, the Paris sedimentary basin to the North, the Aquitaine sedimentary basin to the South and by the Armorican Massif to the Northwest (Figure 1). It is essentially composed of limestone formations dating from the Secondary: (i) in the North, the Jurassic formations are composed of large limestone beds in various facies and, (ii) in the South, the Cretaceous formations are formed by clay, sand, chalk and decalcification clays. The Primary formations crop out in the most upstream catchment areas of the Charente watershed, represented by plutonic and metamorphic rocks (BRGM, 2003).

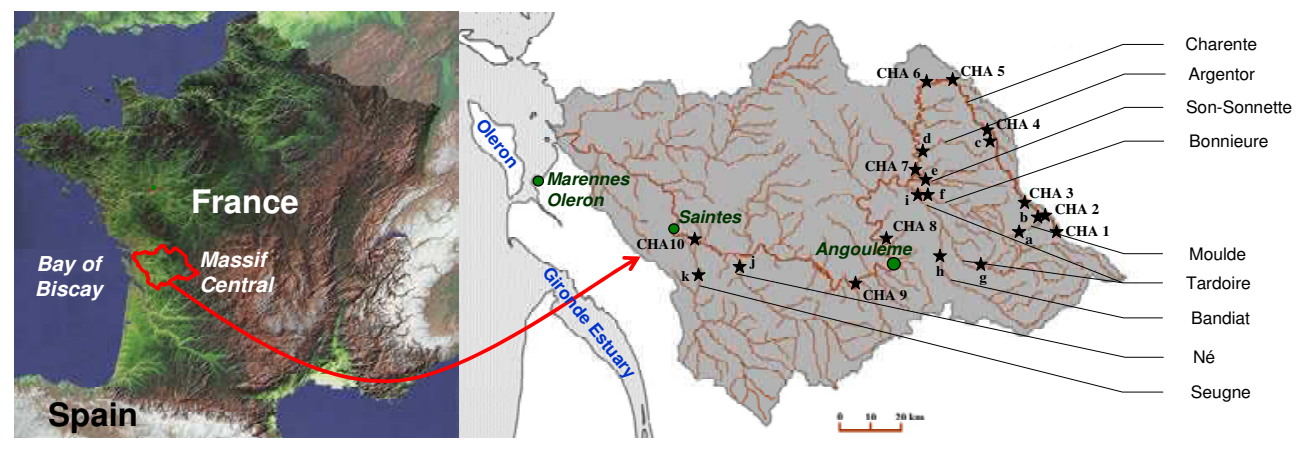

Fig. 1. Location of sampling sites

The Charente watershed can be divided into three main domains (Figure 1):

- The upstream Charente watershed features metamorphic rocks to the East. Two large reservoir dams, the Lavaud reservoir $\left(400 \mathrm{ha} ; 10 \mathrm{Mm}^{3}\right)$ on the Charente River and the 
Mas-Chaban reservoir (176 ha; $14.2 \mathrm{Mm}^{3}$ ) on the Moulde River, were built in 1989-1990. In this section, the Tardoire River is considered the main tributary of the Charente System.

- The downstream Charente River system is located between Angouleme and Saintes, and represented by Quaternary formations. The main tributaries of the Charente River in this section are the Ne and the Seugne Rivers.

- The Charente Estuary, downstream of Saintes, is located in areas where sedimentary rocks and limestone prevail. Two dams have been set up within the estuarine reaches submitted to tidal influence: one at Saint Savinien on the Charente River and the second on the Trezence River, the main tributary of the Boutonne River.

The Charente watershed is considered predominantly as a rural sedimentary basin. Agriculture activities cover about $60 \%$ of this area and about $11 \%$ of the cultivated area is irrigated. However, $52 \%$ of the water bodies in this river system are at risk of failing the European Water Framework Directive objectives to achieve good ecological and chemical status, due to diffuse pollution (nitrates, turbidity, and pesticides) attributed to agricultural activities and practices (EPTB-Charente, 2007; Vernier et al., 2010).

The Charente watershed meteorology is characterized by the Atlantic Ocean disturbances. The mean annual water discharge of the Charente River is $\sim 74 \mathrm{~m}^{3} / \mathrm{s}$, corresponding to a specific discharge (average discharge/watershed area) of $\sim 0.007 \mathrm{~m}^{3} / \mathrm{s} / \mathrm{km}^{2}$, i.e. 3 times less than that of the adjacent Dordogne watershed (Regional Environment Agency- DIREN; BanqueHydro®; Schäfer et al., 2002). Two major factors contribute to this low specific discharge: on the one hand, relatively low supply from its major tributaries (the Tardoire and Bandiat Rivers) flowing over a karst formation and, on the other hand, intense agricultural irrigation throughout the basin. During our sampling campaign, the estimated Charente River water discharge at the watershed was $\sim 100 \mathrm{~m}^{3} / \mathrm{s}$ (Charente River at Chaniers [CHA10; Figure 1] + Boutonne River; data from DIREN), implying that the studied situation is representative of a moderate to a high hydrological situation.

\section{Material and methods}

\subsection{Sampling campaign}

A sampling campaign was conducted from April 6 to April 8 2010. Strategic sites were selected by Geographical Information System (GIS, ArcView ®) for testing different environmental characteristics (e.g. geology, land-use) and evaluating their impacts on Cd concentrations. In total, 20 strategic sites were selected on the Charente River ( $\mathrm{n}=10$ sites; notified by CHA; Figure 1; Table 1) and its tributaries ( $\mathrm{n}=10$ sites; notified by a letter; Figure 1; Table 1) characterized by contrasting geology, industrial and agricultural activities. An additional site was chosen on a small drain near Riou Mort River (former mining area; " $c$ ", Figure 1) for collecting a stream sediment deposit. Note that this Riou Mort River in the Charente watershed is not identical with the well-studied Riou Mort River draining the polluted Decazeville basin, responsible for important historical polymetallic (mainly $\mathrm{Cd}, \mathrm{Zn}, \mathrm{Cu}, \mathrm{Pb}, \mathrm{Hg}, \mathrm{Ag}$ ) pollution in the Lot-Garonne river continuum (e.g. Blanc et al., 1999; Schäfer et al., 2002; Audry et al., 2004; Coynel et al., 2009). 


\begin{tabular}{|c|c|c|c|c|c|c|c|c|c|c|c|c|c|c|}
\hline Item & & River & $\begin{array}{l}\text { Area } \\
\text { km }^{2} \\
\end{array}$ & $\mathrm{~m}^{3}$ & & $\begin{array}{l}\text { Cond. } \\
\mu \mathrm{S} / \mathrm{cm}\end{array}$ & $\mathrm{pH}$ & $\begin{array}{l}\mathrm{eH} \\
\mathrm{mV}\end{array}$ & $\begin{array}{l}\mathrm{O}_{2} \\
\% \\
\end{array}$ & $\begin{array}{l}\text { SPM } \\
\mathrm{mg} / \mathrm{l}\end{array}$ & $\begin{array}{l}\text { Nitrate } \\
\mu \mathrm{mol} / \mathrm{I}\end{array}$ & $\begin{array}{c}\text { Dissolved Cd } \\
\mu \mathrm{g} / \mathrm{I} \\
\end{array}$ & $\begin{array}{c}\text { Part. Cd } \\
\text { SPM mg/kg }\end{array}$ & $\begin{array}{c}\text { Part. Cd } \\
(<63 \mu \mathrm{m}) \mathrm{mg} / \mathrm{kg}\end{array}$ \\
\hline CHA1 & Saint Gervais & Charente & 40 & 0.14 & $\mathrm{X}$ & 86.4 & 7.3 & 101 & 98.4 & 15 & 112 & 0.030 & 3.78 & 1.69 \\
\hline CHA2 & Sansac & Charente & 44 & 1.1 & $\mathrm{x}$ & 96.6 & 7.4 & 95 & 92.5 & 4 & 170 & 0.010 & 2.11 & 0.73 \\
\hline CHA3 & Pont de Suris & Charente & 110 & 2.1 & Diren & 110 & 7.6 & 120 & 91.6 & 12 & 163 & 0.010 & 4.36 & 0.70 \\
\hline CHA4 & Chez Paire & Charente & 230 & 4.5 & $\mathrm{x}$ & 115 & 7.6 & 165 & 90.8 & 10 & 162 & 0.031 & 8.16 & 3.06 \\
\hline CHA5 & Charroux & Charente & 346 & 6.4 & Diren & 207 & 7.5 & 166 & 86.2 & 9 & 223 & 0.020 & 4.86 & 2.63 \\
\hline CHA6 & Saint-Saviol & Charente & 492 & 8.2 & Diren & 226 & 7.6 & 171 & 92.6 & 13 & 259 & 0.022 & 3.51 & 2.29 \\
\hline CHA7 & Aunac & Charente & 1090 & 22 & $\mathrm{x}$ & 373 & 7.8 & 153 & 93.6 & 13 & 415 & 0.011 & 3.07 & 1.39 \\
\hline CHA8 & Vindelle & Charente & 3750 & 47 & Diren & 374 & 8.0 & 227 & 89.7 & 11 & 425 & 0.009 & 2.33 & 0.90 \\
\hline CHA9 & Sireuil & Charente & 4070 & 82 & $x$ & 378 & 8.0 & 205 & 91.0 & 12 & 381 & 0.008 & 2.96 & 2.18 \\
\hline CHA10 & Chaniers & Charente & 7412 & 91 & Diren & 461 & 8.0 & 197 & 90.3 & 9 & 410 & 0.010 & 4.97 & 2.11 \\
\hline a & Massignac & Upstream Moulde & 52 & 0.46 & $\mathrm{x}$ & 98.3 & 7.4 & 85 & 101 & 6 & 114 & 0.009 & 1.20 & 0.82 \\
\hline b & Chez Boige & Downstream Moulde & 54 & 0.96 & $\mathrm{x}$ & 103 & 7.5 & 135 & 99.8 & 2 & 134 & 0.008 & 2.72 & 0.76 \\
\hline c & Riou Mort & - & - & - & - & - & - & - & - & n.d & n.d & n.d & n.d & 37.7 \\
\hline d & Poursac & Argentor & 108 & 2.9 & Diren & 426 & 8.0 & 175 & 102 & 7 & 335 & 0.010 & 3.57 & 1.20 \\
\hline e & Mouton & Son-Sonnette & 226 & 2.7 & $\mathrm{x}$ & 425 & 8.3 & 162 & 115 & 8 & 319 & 0.009 & 3.95 & 1.14 \\
\hline f & Saint Ciers/Bonnieure & Bonnieure & 203 & 2.7 & Diren & 262 & 8.1 & 224 & 103 & 11 & 218 & 0.011 & 2.30 & 0.89 \\
\hline g & Montbron & Upstream Tardoire & 389 & 9.4 & Diren & 87.5 & 7.6 & 94 & 89.4 & 9 & 93 & 0.013 & 4.59 & 1.78 \\
\hline h & Feuillade & Bandiat & 333 & 5.2 & Diren & 176 & 7.8 & 189 & 90.0 & 9 & 100 & 0.009 & 6.17 & 1.70 \\
\hline $\mathbf{i}$ & Coulgens & Downstream Tardoire & 1200 & 8.2 & Diren & 128 & 7.2 & 199 & 98.1 & 23 & 108 & 0.011 & 3.59 & 1.31 \\
\hline $\mathbf{j}$ & Les Perceptiers & $\mathrm{Ne}$ & 602 & 7.4 & Diren & 651 & 8.1 & 202 & 110 & 11 & 477 & 0.009 & 1.80 & 0.72 \\
\hline $\mathbf{k}$ & La Lijardière & Seugne & 902 & 9.9 & Diren & 654 & 7.9 & 212 & 97.0 & 12 & 470 & 0.009 & 2.13 & 0.72 \\
\hline \multicolumn{3}{|c|}{ Charente - CHA10 (2006-2007; Dabrin, 2009) } & & $\begin{array}{l}\text { mean } \\
\min \\
\max \end{array}$ & & & & & & & & $\begin{array}{l}0.024 \\
0.011 \\
0.048 \\
\end{array}$ & $\begin{array}{l}4.89 \\
1.21 \\
9.86 \\
\end{array}$ & \\
\hline
\end{tabular}

Table 1. Description of sampling sites, water discharge obtained by the Regional Environment Agency-DIREN or measured in this study $(X)$, physical and chemical parameter values (conductivity, Eh, $\mathrm{pH}$, dissolved oxygen saturation) and SPM, nitrate, dissolved and particulate Cd (in SPM and stream sediments $<63 \mu \mathrm{m}$ ) concentrations

\subsection{Discharge measurements}

This sampling strategy, aiming at estimating instantaneous fluxes, required reliable discharge data for each of the selected observation sites. However, only 12 sites are equipped with permanent gauging stations maintained by the Regional Environment Agency-DIREN (BanqueHydro®). Therefore, for this study, 8 additional river gauging measurements were performed at the other sampling sites (Table 1). Standard instantaneous discharge measurements were made by measuring flow velocities at different depths along vertical profiles, each of them representing a segment of the river cross-section. The crosssectional area of each segment was then multiplied by the corresponding integrated measured velocities to estimate water discharge in the segment. The sum of river discharges in all segments represents the estimated instantaneous water discharge of the river section. The uncertainty on the measurements was estimated between 5 and 10\% (Regional Environment Agency- DIREN).

\subsection{Water sampling}

The general physical and chemical parameters $\left(\mathrm{pH}\right.$, conductivity, Eh and $\mathrm{O}_{2}$ ) were measured in-situ at each site. Temperature and conductivity were measured using a TetraCon $96 \AA$ probe (PROFILINE, WTW). Oxygen saturation was determined by an ISY $52 \AA$ probe. Determinations of $\mathrm{pH}$ and Eh were performed using a Sentix ${ }^{\circledR} 41$ probe (PROFILINE, WTW). At each site, water was sampled manually for SPM, nitrate and Cd concentrations using clean techniques: all materials in contact with the water samples were made of polypropylene (PP), carefully decontaminated as previously detailed in Canton et al. (2012) for nitrate and in Audry et al. (2004) for Cd. 
Back in the laboratory, river water samples were homogenized and precise volumes $(\sim 500 \mathrm{ml})$ were filtered through pre-weighed $0.7 \mu \mathrm{m}$ filters (Durieu $\left.{ }^{\circledR}\right)$. Then the filters were dried to constant weight $\left(45^{\circ} \mathrm{C} ; 12 \mathrm{~h}\right)$ and re-weighed in order to obtain SPM concentrations. For dissolved nitrate and $\mathrm{Cd}$, all river water samples were immediately filtered on-site through $0.2 \mu \mathrm{m}$ Sartorius ${ }^{\circledR}$ polycarbonate filters. For nitrate, filtrates were collected in $14 \mathrm{ml}$ polypropylene tubes and stored at $-80^{\circ} \mathrm{C}$ until analysis; for dissolved $\mathrm{Cd}$, filtrates were collected in pre-cleaned $30 \mathrm{ml}$ polypropylene bottles, acidified (1/1000; $\mathrm{HNO}_{3}$ suprapur grade) and stored at $4^{\circ} \mathrm{C}$ awaiting analysis.

Suspended particulate matter for $\mathrm{Cd}$ analyses was retrieved by pumping up to $80 \mathrm{~L}$ of river water ( $\sim 50 \mathrm{~cm}$ from the bank at $10-20 \mathrm{~cm}$ depth) using a peristaltic pump with PP-tubing followed by centrifugation (Westfalia, Germany; $12,000 \mathrm{~g}$ ). This technique is considered a practicable and reliable method for SPM sampling in all hydrological situations (e.g. Schäfer \& Blanc, 2002).

\subsection{Stream sediment sampling}

Stream sediments are commonly used for geochemical prospecting. Collected just after a strong hydrological event, the geochemical composition of these samples corresponds to the maximum particulate transfer to the estuary and coastal zone. Unlike SPM, whose composition can rapidly fluctuate, stream sediments integrate metal contamination (Coynel et al., 2009).

The coordinates of the sampling locations were recorded with a differential GPS. At each site, representative samples, consisting of the uppermost $1 \mathrm{~cm}$ of sediment from several recent depositional pockets were collected with a plastic spatula within a distance of 5-10 meters to enhance representativeness. The preferential accumulation of metals, either of natural or anthropogenic origin, in the fine-grained sediment fractions may induce grain size effects and reduced sample representativeness (Förstner \& Wittmann, 1981; Horowitz, 1991; Benoit \& Rozan, 1998). Therefore, stream sediment samples were sieved $(<63 \mu \mathrm{m}$; nylon sieves) to remove coarse material which was obviously not representative of typical grain size of suspended sediment (Coynel et al., 2009).

\subsection{Nutrient analysis}

The dissolved inorganic compounds were colorimetrically analyzed according to standardized techniques. Dissolved nitrates $\left(\Sigma \mathrm{NO}_{3}{ }^{-}=\mathrm{NO}_{3^{-}}+\mathrm{NO}_{2}{ }^{-}\right)$were analyzed by Flow Injection Analysis (FIA) according to Canton et al. (2012). Precision was $\pm 10 \%$ for $\Sigma \mathrm{NO}_{3}{ }^{-}$.

\subsection{Particulate Cd extraction in SPM and stream sediment}

Representative subsamples ( $\sim 30 \mathrm{mg}$ of dry, powdered and homogenized material) of SPM or sediment were digested in acid-cleaned closed reactors using $1.5 \mathrm{ml} \mathrm{HCl} \mathrm{s.p.} \mathrm{(12} \mathrm{M),} 2 \mathrm{ml}$ HF s.p. $(22 \mathrm{M})$ and $0.75 \mu 1 \mathrm{HNO}_{3}$ s.p. $(14 \mathrm{M})$ at $110^{\circ} \mathrm{C}$ for $2 \mathrm{~h}$ using a temperature-controlled digestion system (DigiPREP MS®, SCP SCIENCE). After evaporation to dryness $(10 \mathrm{~h}$ at $110^{\circ} \mathrm{C}$ ), the residues were completely re-dissolved in $0.25 \mathrm{ml} \mathrm{HNO}_{3}$ s.p. $(14 \mathrm{M})$ and $5 \mathrm{ml}$ Milli-Q ${ }^{\circledR}$ water on a heating plate $\left(15 \mathrm{~min}\right.$ at $\left.60^{\circ} \mathrm{C}\right)$ and after cooling brought to $10 \mathrm{ml}$ in volumetric flasks using Milli-Q® water. 


\subsection{Dissolved and particulate Cd analysis}

Dissolved and particulate Cd concentrations were measured using ICP-MS (X7, THERMO) with external calibration under standard conditions. The applied analytical methods were continuously quality checked by analysis of international certified reference sediments (PACS-1, BCR 320, SL-1, SLRS-4). Accuracy was within 5\% and 7\% of the certified values in the dissolved and particulate fractions, respectively. The analytical error (relative standard deviation) was better than $5 \%$ (rsd) for both phases. The detection limit estimated as 3 sigma of method blanks was $2 \mathrm{ng} / 1$ for the dissolved phase and $0.04 \mathrm{mg} / \mathrm{kg}$ for the particulate phase.

\section{Results and discussion}

\subsection{Physical and chemical parameters}

Conductivity, redox potentials (Eh) and $\mathrm{pH}$ (to a lesser extent) in the Charente River and its tributaries tended to increase from upstream to downstream, probably reflecting local geological characteristics (metamorphic rocks in the upstream sections; limestone formations in the downstream watershed) and land use (vineyards). The dissolved oxygen saturation values were rather similar whatever the sites (Table 1).

\subsection{Discharge monitoring}

The spatial variability of the Charente River water discharge is linearly related to its drainage basin area for the section between $\mathrm{CHA} 1$ and $\mathrm{CHA}$, except for $\mathrm{CHA} 8$ (Figure 2).

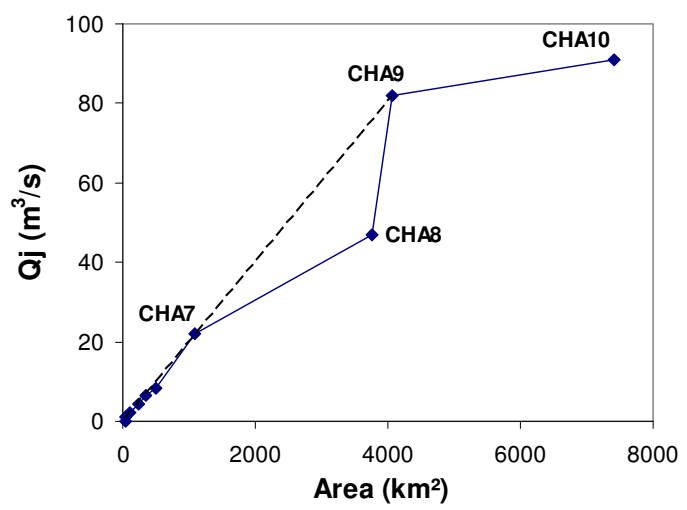

Fig. 2. Relationship between daily water discharges measured at different sites of the Charente River and the corresponding surface areas

The permanence of shoal sedimentation during the Middle and Upper Jurassic is a local feature which explains the development of the La Rochefoucauld karstic system, close to Angouleme city (Figure 1) and the relatively low water discharge measured at CHA8. The Bandiat and the Tardoire Rivers flow over the La Rochefoucauld karst accounting for more than $50 \%$ of the outlet discharges (Kurtulus \& Razack, 2007). The La Touvre spring, located near of Angouleme city, constitutes an important discharge system of the aquifer varying 
between $2 \mathrm{~m}^{3} / \mathrm{s}$ and $40 \mathrm{~m}^{3} / \mathrm{s}$. During our water monitoring campaign, the La Touvre water discharge was $\sim 19.3 \mathrm{~m}^{3} / \mathrm{s}$. The apparent water discharge deficit at CHA10 compared to the general relation between discharge and area drained may reflect the intense agricultural irrigation (Figure 2).

\subsection{SPM measurements}

The SPM concentrations ranged from $2 \mathrm{mg} / 1$ in the Moulde River, just after the Mas-Chaban Reservoir to $23 \mathrm{mg} / 1$ in the Tardoire River (Table 1). The lowest value can be explained because of hard to erode rock sills combined with the settling of SPM due to the presence of the Mas-Chaban Reservoir. Based on the world river classification of SPM concentration proposed by Meybeck et al. (2003), these values can be considered as either "very low" $(<20 \mathrm{mg} / \mathrm{l})$, generally observed for watersheds located downstream of major or numerous lakes (e.g. Alpine Rhone River), or in very flat and humid regions with wetland predominating (e.g. the Central Amazon watershed) or "low" (20-100 mg/l) characteristic of plain watersheds. However, even if our sampling campaign is representative of a moderate to high discharge hydrological situation $\left(\mathrm{Q}=\sim 100 \mathrm{~m}^{3} / \mathrm{s}\right)$, SPM concentrations probably are much higher during flood events as previously observed by Dabrin (2009), during 20062007, at the outlet of the Charente watershed (Chaniers site; SPM $=200 \mathrm{mg} / 1$ during a flood event with $\mathrm{Q}=350 \mathrm{~m}^{3} / \mathrm{s}$ )

\subsection{Nitrate concentrations}

The nitrate concentrations were 93-477 $\mu \mathrm{M} / 1$ with an average $\sim 246 \mu \mathrm{M} / 1$ (Table 1). Nitrate concentrations measured in the main hydrological section of the Charente River increased from upstream $(\sim 100 \mu \mathrm{M} / 1)$ to downstream (up to $425 \mu \mathrm{M} / 1$ at CHA8) and were positively correlated to water discharge at the watershed scale (Figure 3). This clear nitrate increase

A

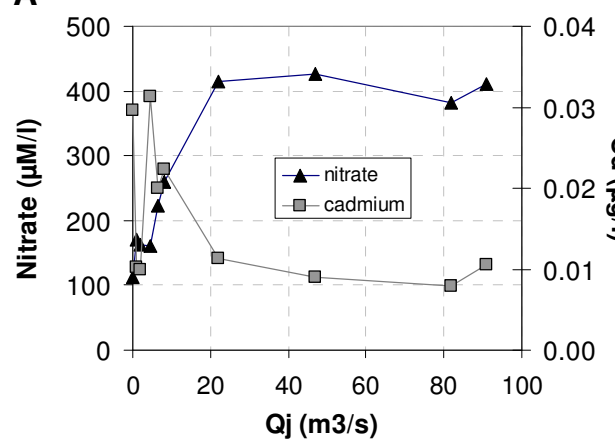

B

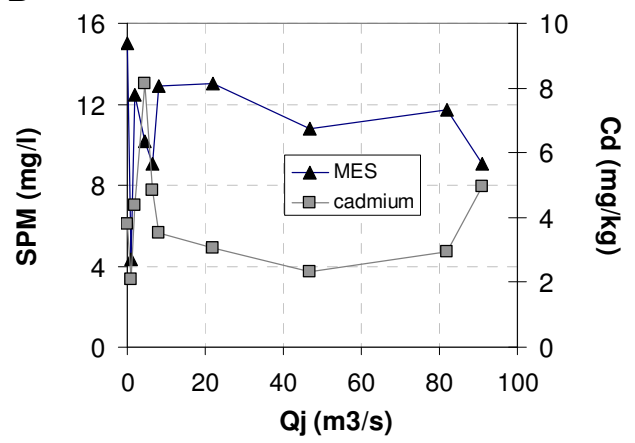

Fig. 3. (A) Nitrate and dissolved Cd concentrations versus daily water discharge in the Charente River; (B) Suspended Particulate Matter (SPM) and particulate Cd concentrations versus daily water discharge in the Charente River. 
starts at the CHA5 site, i.e. where the Charente River drains maize areas. Based on this observation, we have determined typical nitrate concentrations for each land use in the Charente System: the mean nitrate concentrations are $\sim 140 \mu \mathrm{M} / 1$ in the areas mainly occupied by pasture, $\sim 350 \mu \mathrm{M} / 1$ for corn/maize production and $\sim 430 \mu \mathrm{M} / 1$ in vineyard areas.

The Charente River faces high nitrate levels (Bry \& Hoflack, 2004; EPTB-Charente, 2007). These high levels probably reflect the intensification of agriculture in the central and lower systems and increase the risk of eutrophication. The intensification of crops, particularly corn production, was accompanied by a high water demand for irrigation over the last thirty years. Vineyards are also located in the basin and can generate diffuse water pollution by nitrates. To assess whether the concentrations obtained on the Charente River are comparable to other systems, we compared our results with those recently published for rivers draining the Arcachon basin (SW France), which is affected by eutrophication due to nitrogen transfer from agricultural areas to the river system (Canton et al., 2012). These authors demonstrated that low concentrations (20 to $45 \mu \mathrm{M} / \mathrm{l}$ ) occur in watersheds dominated by forest, whereas nitrate concentrations were considered as high in watersheds draining agricultural areas with an average of $140 \mu \mathrm{M} / 1$ (Canton et al., 2012). For these agricultural watersheds, nitrate concentrations increased from 200 to $500 \mu \mathrm{M} / 1$ in winter during high water discharges. Accordingly, our results obtained for the Charente River are similar to those in the rivers studied by Canton et al. (2012) supporting that the high nitrate concentrations may be attributed to agriculture as suggested previously (Bry \& Hoflack, 2004; Vernier et al., 2010) and probably result in significant nitrate export to the MarennesOleron Bay and the adjacent coastal area.

\subsection{Dissolved Cd concentrations}

The dissolved Cd concentrations $\left(\mathrm{Cd}_{\mathrm{D}}\right)$ in the Charente watershed ranged from 8 to $31 \mathrm{ng} / \mathrm{l}$, with an average of $\sim 17 \mathrm{ng} / 1$ (Table 1). Unlike the spatial nitrate evolution, the dissolved $\mathrm{Cd}$ concentrations in the mainstream decreased from upstream to downstream until CHA9; then a slight $C d_{D}$ increase occurred at CHA10 (Figure 3). Based on the $C d_{D}$ levels, a $C d_{D}$ distribution map aims at visualizing the spatial variation in the Charente watershed (Figure 4). The color classes were determined using the detection limit $(2 \mathrm{ng} / \mathrm{l})$, the $\mathrm{Cd}_{\mathrm{D}}$ level (10 ng/l) representing "good status" of water quality as proposed by the Ministry of Environment and Sustainable Development and the Water Agencies quality guideline (SEQeau; MEDD and Agences de l'Eau, 2003) and the average $C_{D}$ in world rivers proposed by Martin \& Meybeck (1979) marked MA in Figure 4 (MA=50 ng/l).

In the downstream Charente watershed, the Seugne, Né, Sonnette and Bandiat Rivers showed $\mathrm{Cd}_{\mathrm{D}}$ typical of good water quality $(<10 \mathrm{ng} / \mathrm{l})$, as well as the upstream sections of the Moulde, the Argentor and the Son-Sonnette Rivers. In contrast, the $C d_{D}$ concentrations in the upstream section of the Charente River (CHA1; CHA4-CHA6) suggested lower water quality (20-30 ng/l; Table 1$)$. However, even the highest $\mathrm{Cd}_{\mathrm{D}}$ measured in this study were lower than the $\mathrm{Cd}_{\mathrm{D}}$ level defined for the world's major rivers $(\mathrm{MA}=50 \mathrm{ng} / \mathrm{l}$; Figure 4), with low human influences (e.g. Amazon and Congo Rivers; Martin \& Meybeck, 1979). 


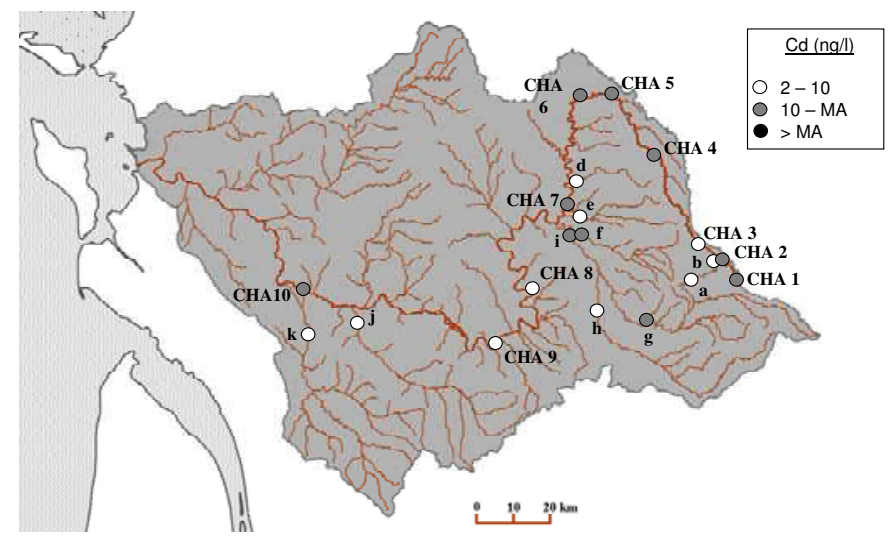

Fig. 4. Spatial distribution of dissolved Cd concentrations

\subsection{Particulate Cd concentrations in SPM}

The particulate $\mathrm{Cd}$ concentrations $\left(\mathrm{Cd}_{\mathrm{P}}\right)$ were variable from one site to another with values comprised between $1.20 \mathrm{mg} / \mathrm{kg}$ and $8.16 \mathrm{mg} / \mathrm{kg}$ (Table 1 ). Most of these values were clearly higher than the average concentration measured in the SPM defined for Word Rivers (MA=1.55 mg/kg; Viers et al., 2009), except for the Upstream Moulde River (Table 1). As observed for $\mathrm{Cd}_{\mathrm{D}}$ in the main hydrological section of the Charente watershed, the $C \mathrm{~d}_{\mathrm{P}}$ concentrations in SPM decreased from upstream to downstream until CHA9; then a significant $\mathrm{Cd}$ increase occurred at $\mathrm{CHA10}$ (Figure 3). The spatial evolution of the particulate $\mathrm{Cd}$ concentration is not correlated with that of the Charente SPM concentrations (Figure 3). We compared particulate $\mathrm{Cd}$ concentrations with consensus-based sediment quality guidelines proposed for freshwater sediments (MacDonald et al., 2000), i.e. concentration classes supporting the assessment of ecotoxicological risk potential (Figure 5).

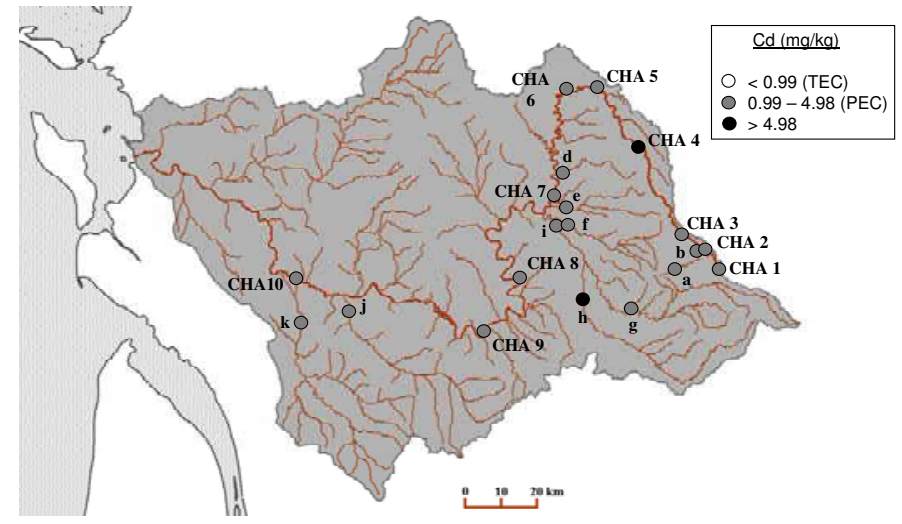

Fig. 5. Spatial distribution of particulate Cd concentrations in SPM

- The TEC (Threshold Effect Concentration; $\mathrm{Cd}_{\mathrm{P}}=0.99 \mathrm{mg} / \mathrm{kg}$ ) is defined as the $\mathrm{Cd}$ concentration below which no effect on organisms is expected; 
- The PEC (Probable Effect Concentration; $\mathrm{Cd}_{\mathrm{P}}=4.98 \mathrm{mg} / \mathrm{kg}$ ) is defined as the $\mathrm{Cd}_{\mathrm{P}}$ concentration above which effects on organisms are expected.

Most of the $C d_{P}$ in the Charente River SPM were higher than the TEC and at two sites the measured values exceeded the PEC level (" $\mathrm{b}$ " and "CHA4" with $\mathrm{Cd}_{\mathrm{P}}=6.17$ and $8.16 \mathrm{mg} / \mathrm{kg}$, respectively); two other sites (CHA10; $\mathrm{CHA5}$ ) have values close to the PEC level (Figure 5). These results suggest that in the Charente River system toxic effects on aquatic organisms due to the presence of $\mathrm{Cd}$ (i) cannot be excluded at most of the sites studied and (ii) should be expected locally.

\subsection{Particulate Cd concentrations in stream sediments $(<63 \mu \mathrm{m})$}

Excluding the Riou Mort site " $c$ " $(\mathrm{Cd}=37.7 \mathrm{mg} / \mathrm{kg})$ which drains a former mineral resource deposit, $\mathrm{Cd}_{\mathrm{P}}$ in sieved stream sediments ranged from 0.70 to $3.06 \mathrm{mg} / \mathrm{kg}$ (Table 1 ). The comparison with ecotoxicological indices showed that a majority of sites have $\mathrm{Cd} P$ concentrations above the TEC, yet without exceeding the PEC level (Figure 6). This suggests that potential toxicity effects on water organisms in the Charente River due to the presence of Cd cannot be excluded.

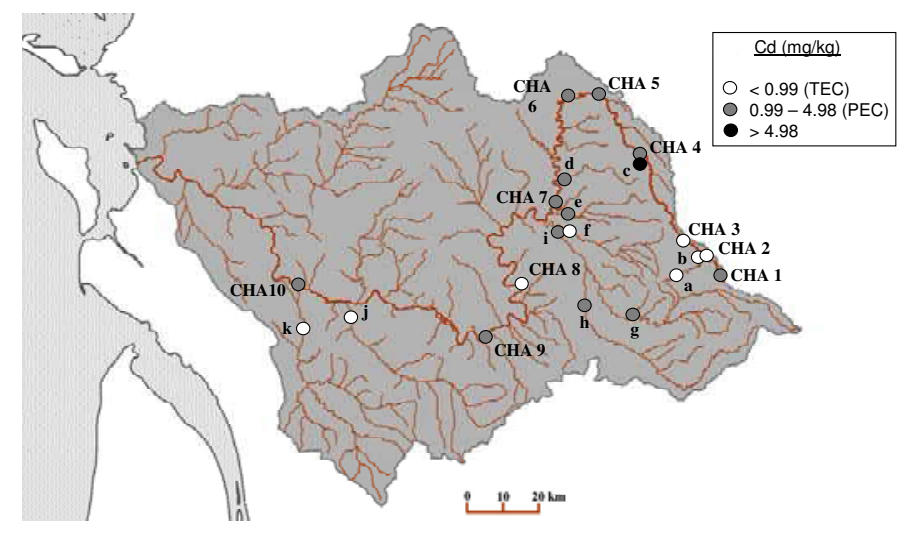

Fig. 6. Spatial distribution of particulate Cd concentrations in $<63 \mu \mathrm{m}$ sediments

\subsection{Comparison with the geochemical monitoring performed during 2006-2007}

The dissolved and particulate Cd concentrations measured at the Chaniers site (CHA10 site) in this study were compared with those obtained during the 2 year-geochemical monitoring achieved in the Inter-Regional project "Défi Cadmium" (Cadmium Challenge, Water Agency Adour-Garonne) performed during 2006 and 2007 (Dabrin, 2009; Table 1). The Chaniers site is considered as the outlet of the fluvial Charente watershed. The $\mathrm{Cd}_{\mathrm{P}}$ in SPM from CHA10 measured in this study was similar to average $\mathrm{Cd}_{\mathrm{P}}$ established during the "Défi Cadmium" project. In contrast, the $C_{D}$ concentration was lower than the minimum $\mathrm{Cd}_{\mathrm{D}}$ value measured by Dabrin (2009). It has been classically observed in river systems that the lowest metal concentrations in water and in SPM occurred during high flow rates. This phenomenon can be related to dilution by (i) rainwater for the dissolved phase and (ii) coarse particles (coarse silt to sand) with low metal adsorption capacity for the particulate 
phase (e.g. Schleichert, 1975; Dawson \& Macklin, 1998; Cobelo-Garcia et al., 2004). In the Charente River system, Dabrin (2009) showed that the dissolved concentrations of some metals such as $\mathrm{Cd}$ decreased with water discharges, highlighting the close link between hydrology and geochemistry. As our campaign is representative of "medium to high water" conditions in the Charente River, our evaluation of the SPM quality defined throughout the watershed does not represent the worst geochemical situation. We can therefore assume that $\mathrm{Cd}_{\mathrm{P}}$ may frequently exceed critical thresholds (e.g. PEC) at many sites during low waters and we recommand specific water monitoring during this period in order to evaluate ecotoxicological risk at the watershed scale.

\subsection{Dissolved and particulate Cd fluxes}

The instantaneous (daily) dissolved and particulate $\mathrm{Cd}$ fluxes were calculated for each sampling site (Table 2). The $\mathrm{Cd}_{\mathrm{D}}$ levels significantly increased between the $\mathrm{CHA} 3$ and the CHA4 sites, inducing a clear increase in $\mathrm{Cd}_{\mathrm{D}}$ flux that was not proportional to water discharge, suggesting an additional point source within this section (Figure 7A). The additional Cd point source $(\Delta 1 \sim 8 \mathrm{~g} / \mathrm{d}$; Figure $7 \mathrm{~A})$ may be linked to the presence of mineral deposits in the metamorphic formation areas and specifically, near the fault of Beaumont Confolent (BRGM, 2003). This is supported by high $\mathrm{Cd}_{\mathrm{P}}$ measured in the sediment collected in the former mining area (site " $c$ "; Figure 1). A second abnormal increase in $\mathrm{Cd}_{D}$ fluxes $(\Delta 2 \sim 25 \mathrm{~g} / \mathrm{d}$; Figure 7A) can be observed between the CHA9 and the CHA10 sites and cannot be explained by the $\mathrm{Cd}_{\mathrm{D}}$ supply via the Ne and Seugne Rivers alone (" $\mathrm{j}$ " and " $\mathrm{k}$ "; Table 2). Additional campaigns will be needed to identify the source in this section by performing a longitudinal profile along the Charente River. Note that in this geographical area, we have located a manufactury which produces batteries for all types of civil and military aircrafts.

\begin{tabular}{|c|c|c|c|c|c|c|}
\hline Item & & River & $\begin{array}{c}\text { SPM Flux } \\
t / j\end{array}$ & $\begin{array}{c}\text { Part Cd flux } \\
\text { g/j }\end{array}$ & $\begin{array}{c}\text { Diss Cd flux } \\
g / j\end{array}$ & $\begin{array}{l}\text { Part Cd flux } \\
\text { contribution }\end{array}$ \\
\hline CHA1 & Saint Gervais & Charente & 0.2 & 0.7 & 0.4 & $66 \%$ \\
\hline CHA2 & Sansac & Charente & 0.4 & 0.8 & 0.9 & $47 \%$ \\
\hline CHA3 & Pont de Suris & Charente & 2.2 & 10 & 1.8 & $85 \%$ \\
\hline CHA4 & Chez Paire & Charente & 4.0 & 32 & 12 & $73 \%$ \\
\hline CHA5 & Charroux & Charente & 5.0 & 24 & 11 & $69 \%$ \\
\hline CHA6 & Saint-Saviol & Charente & 9.1 & 32 & 16 & $67 \%$ \\
\hline CHA7 & Aunac & Charente & 25 & 76 & 21 & $78 \%$ \\
\hline CHA8 & Vindelle & Charente & 44 & 102 & 36 & $74 \%$ \\
\hline CHA9 & Sireuil & Charente & 83 & 245 & 56 & $81 \%$ \\
\hline CHA10 & Chaniers & Charente & 71 & 353 & 82 & $81 \%$ \\
\hline $\mathbf{a}$ & Massignac & Upstream Moulde & 0.2 & 0.3 & 0.3 & $45 \%$ \\
\hline b & Chez Boige & Downstream Moulde & 0.2 & 0.5 & 0.7 & $40 \%$ \\
\hline c & Riou Mort & - & - & - & - & - \\
\hline d & Poursac & Argentor & 1.8 & 6.3 & 2.4 & $72 \%$ \\
\hline e & Mouton & Son-Sonnette & 1.8 & 7.1 & 2.2 & $77 \%$ \\
\hline f & Saint Ciers/Bonnieure & Bonnieure & 2.5 & 5.9 & 2.6 & $69 \%$ \\
\hline g & Montbron & Upstream Tardoire & 7.2 & 33 & 11 & $76 \%$ \\
\hline h & Feuillade & Bandiat & 3.9 & 24 & 4.2 & $85 \%$ \\
\hline $\mathbf{i}$ & Coulgens & Downstream Tardoire & 16 & 59 & 8.1 & $88 \%$ \\
\hline $\mathbf{j}$ & Les Perceptiers & $\mathrm{Ne}$ & 7.3 & 13 & 5.7 & $70 \%$ \\
\hline $\mathbf{k}$ & La Lijardière & Seugne & 11 & 22 & 8.0 & $74 \%$ \\
\hline
\end{tabular}

Table 2. Daily SPM flux and dissolved and particulate Cd flux and particulate Cd flux contribution at strategic sites 
The evolution of the daily $\mathrm{Cd}_{\mathrm{P}}$ flux in the section of the Charente River was compared to that of the corresponding SPM flux. This comparison revealed a good statistical relationship between both parameters (Figure 7B). Based on this relationship, we can define a $\mathrm{Cd}_{\mathrm{P}}$ average of $\sim 2.90 \mathrm{mg} / \mathrm{kg}$, corresponding to the regression slope and, probably, to the $\mathrm{Cd} P$ level in agricultural lands which are mechanical eroded during runoff. Based on this, we have detected a small increase in $C_{P}$ that was not due to the contribution of SPM at the CHA4 site and a strong $C_{P}$ anomaly at the CHA10 site. Like for $C_{D}$, the minor $C d_{P}$ anomaly in CHA4 probably results from the presence of formerly exploited mineral deposits (Ba-Pb-Zn mineralization). Between the CHA9 and CHA10 sites, we have observed a SPM decrease related to sedimentation inducing decreasing SPM fluxes ('loss') in this section. Based on the observed relationship between SPM flux and $\mathrm{Cd}_{\mathrm{P}}$ flux in the Charente River, the expected $C d_{P}$ flux at the Chaniers site for an instantaneous SPM flux of $71 \mathrm{t} / \mathrm{d}$ would be $\sim 200 \mathrm{~g} / \mathrm{d}$ (Figure 7B). The observed $\mathrm{Cd}_{\mathrm{P}}$ flux of $353 \mathrm{~g} / \mathrm{d}$ being $\sim 1.8$ times higher (Table 2) clearly suggests a significant $\mathrm{Cd}$ enrichment in SPM due to anthropogenic sources and reflects observations made for $\mathrm{Cd}_{\mathrm{D}}$.
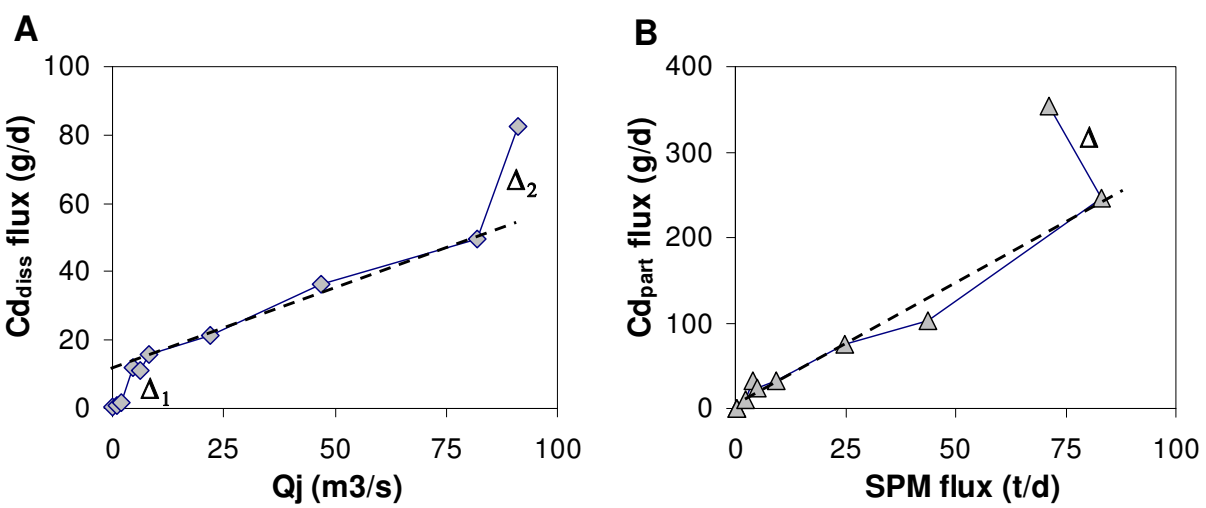

Fig. 7. Relationship between daily dissolved Cd flux and water discharge (A) and between daily particulate Cd flux and SPM flux (B) at strategic sites in the main channel of the Charente River

The dissolved and particulate flux estimates underline the $\mathrm{Cd}$ partitioning (i.e chemical form) in the Charente River system. In the main section of the Charente River, the instantaneous Cd flux was mainly due to SPM transport (reaching 80\% at CHA10), except at CHA2 (downstream from the Lavaud Reservoir) and in the Moulde River (upstream and downstream part), where the particulate transport contributed $47 \%, 45 \%$ and $40 \%$, respectively, to total (dissolved + particulate) $\mathrm{Cd}\left(\mathrm{Cd}_{\mathrm{T}}\right)$ fluxes. These results suggest that the particulate phase is the predominant $\mathrm{Cd}$ vector in the Charente River system and demonstrate that efficient reduction of $\mathrm{Cd}$ transport into the Marennes-Oleron Bay would imply limitation of mechanical erosion, mainly in the agricultural areas.

By extrapolating daily fluxes to the annual scale, we have obtained a first approximation of annual SPM and Cd exports to the Charente Estuary and in fine to the MOB. These estimates probably represent the orders of magnitude, although errors on flux estimates 
related to inadequate sampling frequency may be very high and are likely to result in severe under-estimation of fluxes (Coynel et al., 2004). Based on this extrapolation, annual SPM flux and $\mathrm{Cd}_{\mathrm{T}}$ export at CHA10 were evaluated to $\sim 26,000 \mathrm{t} / \mathrm{yr}$ and $159 \mathrm{~kg} / \mathrm{yr}$, respectively, corresponding to a specific sediment yield of $\sim 2.45 \mathrm{t} / \mathrm{km}^{2} / \mathrm{yr}$ and a specific $\mathrm{Cd}_{\mathrm{T}}$ flux $15 \mathrm{~g} / \mathrm{km}^{2} / \mathrm{yr}$. Accordingly, the specific (potentially under-estimated) $\mathrm{Cd}$ flux of the Charente watershed would be 2 times lower than that of the Cd-polluted Garonne watershed in 2006/2007 (39 g/ km²/yr; Dabrin, 2009). However, as explained above, this Cd estimation for the Charente River system is probably highly underestimated. Indeed, based on a permanent observation sampling in 2006-2007 with high temporal resolution, the annual specific CdT was evaluated to $54 \mathrm{~g} / \mathrm{km}^{2} / \mathrm{yr}$ for the Charente River, i.e. higher of that reported for the Garonne River (Dabrin, 2009). Furthermore the totality of Cd exported from the Charente watershed via the Charente Estuary directly enters the MOB and may reach the oyster farms therein, whereas only part of the $\mathrm{Cd}$ exported from the Gironde system may reach the vulnerable zones of the MOB. Our work intends to demonstrate that the Charente River system should be further studied because of its significant impact on the MOB.

\section{Conclusion}

This study represents a major advance in the geochemical characterization of water and water-borne particles in the Charente River and contributes to a better understanding of the $\mathrm{Cd}$ transfer into the Marennes-Oleron Bay. The main results obtained have allowed to:

- develop a first spatially resolved geochemical database of dissolved and particulate $\mathrm{Cd}$ concentrations at the watershed scale, i.e. in three different compartments (water, sediment and SPM) at 21 strategic sites along the Charente River and its tributaries, taking into account the geology and land use characteristics;

- assess the quality of these three geochemical compartments using ecotoxicological criteria or world river references and locate sub-catchment with potential chemical risk;

- quantify the daily dissolved and particulate $\mathrm{Cd}$ fluxes representative of a moderate hydrological situation from the water discharge measurements provided by the Regional Environment Agency-DIREN and complemented by gauging measurements during this campaign;

- $\quad$ estimate the Cd contribution from subcatchments and identify major zones with point and/or diffuse Cd sources.

In terms of perspectives, further work should be carried out during low water because of the strong relationship between water quality and hydrology. It would also be necessary to determine more precisely the origins of the observed $\mathrm{Cd}$ anomaly, by taking samples from the former mining deposit and agricultural soils. This approach should be completed by a longitudinal sampling profile between $\mathrm{CHA} 9$ and $\mathrm{CHA} 10$, where significant additional dissolved and particulate $\mathrm{Cd}$ fluxes occurred. Our study includes the Charente River upstream from the Chaniers site, which is considered as the outlet of the fluvial system. Furthermore, a more complete mass balance should include fluxes via two other major tributaries, the Boutonne and Arnoult Rivers, entering the Charente Estuary in the tidal reaches. 


\section{References}

Audry, S., Schäfer, J., Blanc, G. \& Jouanneau, J.M. (2004). 50-year sedimentary record of heavy metal pollution $(\mathrm{Cd}, \mathrm{Zn}, \mathrm{Cu}, \mathrm{Pb})$ in the Lot River reservoirs (France), Environmental Pollution, 132, pp. 413-426.

Baeyens, W., Elskens, M., Van Ryssen, R. \& Leermakers, M. (1997). The impact of the Scheldt input on the trace metal distribution in the Belgian coastal area (results of 1981-1983 and 1995-1996), Hydrobiologia, 366, pp. 91-108.

Benoit, G. \& Rozan, T.F. (1999). The influence of size distribution on the particle concentration effect and trace metal partitioning in rivers, Geochimica et Cosmochimica Acta, 63, pp. 113-127.

Blanc, G., Lapaquellerie, Y., Maillet, N. \& Anschutz, P. (1999). A cadmium budget for the Lot-Garonne fluvial system (France), Hydrobiologia, 410, pp. 331-341.

Boutier, B., Chiffoleau, J.-F., Gonzalez, J.-L., Lazure, P., Auger, D. \& Truquet, I. (2000). Influence of the Gironde estuary outputs on cadmium concentrations in the coastal waters: consequences on the Marennes-Oléron bay (France), Oceanologica Acta, 23, pp. 745-757.

BRGM-Bureau de Recherches Géologiques et Minières (2003). Carte géologique de la France $1: 1000000$.

Bry, C. \& Hoflack, P. (2004). Le bassin versant de la Charente : une illustration des problèmes posés par la gestion quantitative de l'eau, Courrier de l'environnement de l'INRA, 52. pp. 81-84.

Canton, M., Anschutz, P., Coynel, A., Polsenaere, P., Auby, I. \& Poirier, D. (2012). Nutrient export to an Eastern Atlantic coastal zone: first modeling and nitrogen mass balance, Biogeochemistry, 107, pp. 361-377

Castelle, S., Schäfer, J., Blanc, G., Audry, S., Bossy, C. \& Lissalde, J.P. (2007). 50-year record and solid state speciation of mercury in natural and contaminated reservoir sediment, Applied Geochemistry, 22, pp. 1359-1370.

Chiffoleau, J.M., Auger, D. \& Chartier, E. (1999). Fluxes of selected trace metals from the Seine Estuary to the Eastern English Channel during the period August 1994 to July 1995, Continental Shelf Research, 19(15-16), pp. 2063-2082.

Cobelo-Garcia, A., Prego, R. \& Labandeira, A. (2004). Land inputs of trace metals, major elements, particulate organic carbon and suspended solids to an industrial coastal bay of the NE Atlantic, Water Research 38, pp. 1753-1764.

Coynel, A., Schafer, J., Hurtrez, J.E., Dumas, J., Etcheber, H. \& Blanc, G. (2004). Sampling frequency and accuracy of SPM flux estimates in two contrasted drainage basins, Science of the Total Environment, 330, 233-247.

Coynel, A., Schafer, J., Blanc, G. \& Bossy, C. (2007). Scenario of particulate trace metal and metalloid transport during a major flood event inferred from transient geochemical signals, Applied Geochemistry, 22, pp. 821-836.

Coynel, A., Blanc, G., Marache, A., Schäfer, J., Dabrin, A., Maneux, E., Bossy, C., Masson, M. \& Lavaux, G. (2009). Assessment of metal contamination in a small mining-affected watershed - high resolution monitoring coupled with spatial analysis by GIS, Journal of Environmental Monitoring, 11, pp. 962-976.

Dabrin, A. (2009). Mécanismes de transfert des éléments traces métalliques (ETM) et réactivité estuarienne - Cas des systèmes Gironde, Charente, Seudre et Baie de Marennes Oléron. Thèse de doctorat, Univ. Bordeaux 1, 375 p. 
Dawson, E.J. \& Macklin, M.G. (1998). Speciation of heavy metals on suspended sediment under high flow conditions in the River Aire, West Yorkshire, UK, Hydrological Processes 12, pp. 1483-1494.

EPTB-Charente (2007). Association française des Etablissements Publics Territoriaux de bassin. http://www.eptb.asso.fr/les-eptb/eptb-charente.

Förstner, U. \& Wittmann, G.T.W. (1981). Metal Pollution in the Aquatic Environment. New York, Springer-Verlag, 486 pp.

Gonzalez, J.L., Boutier, B., Chiffoleau, J.F., Auger, D., Noel, J. \& Truquet, I. (1991). Distribution of $\mathrm{Cd}$ and $\mathrm{Hg}$ in the Bay of Marennes-Oleron, Oceanologica Acta, 14, pp. 559-568.

Goulletquer, P. \& Heral, M. (1997). Marine molluscan production trends in France: from fisheries to aquaculture in: C.L. Mackenzie, Jr. V.G. Burnell, Jr., A. Rosenfield, \& W.L. Hobart (Eds). The history, present condition and future of the molluscan fisheries of North and Central America and Europe Volume 3, Europe. NOAA Technical Report NMFS, 129, pp. 137-164.

Horowitz, A.J. (1991). A primer on sediment-trace element chemistry. Chelsea, Lewis Publishing Co, 2nd edition, $136 \mathrm{p}$.

Kurtulus, B. \& Razack, M. (2007). Evaluation of the ability of an artificial neural network model to simulate the input-output responses of a large karstic aquifer. The La Rochefoucauld aquifer (Charente, France), Hydrogeology Journal, 15, pp. 241-254.

Lanceleur, L., Schäfer, J., Bossy, C., Coynel, A., Larrose, A., Masson, M. \& Blanc, G. (2011). Silver fluxes to the Gironde Estuary - Eleven years (1999-2009) of monitoring at the watershed scale, Applied Geochemistry, 26, pp. 797-808.

Larrose, A., Coynel, A., Schafer, J., Blanc, G., Masse, L. \& Maneux, E. (2010). Assessing the current state of the Gironde Estuary by mapping priority contaminant distribution and risk potential in surface sediment, Applied Geochemistry, 25, pp. 1912-1923.

MacDonald, D.D., Ingersoll, C.G. \& Berger, T.A. (2000). Development and Evaluation of consensus-Based Sediment Quality Guidelines for Freshwater Ecosystems, Archives of Environmental Contamination and Toxicology, 39, pp. 20-31.

Martin J.M., Meybeck M. (1979). Elemental mass-balance of material carried by major world rivers, Marine Chemistry, 7, pp. 173-206.

Masson, M., Blanc, G. \& Schäfer, J. (2006). Geochemical signals and source contributions to heavy metal $(\mathrm{Cd}, \mathrm{Zn}, \mathrm{Pb}, \mathrm{Cu})$ fluxes into the Gironde Estuary via its major tributaries, Science of the Total Environment, 370, pp. 133-146.

MEDD \& Agences de l'Eau (2003). Système d'évaluation de la qualité de l'eau des cours d'eau (SEQ-EAU; version 2), http:/ / rhin-meuse.eaufrance.fr/IMG/pdf/grilles-seqeau-v2.pdf; 40p.

Meybeck, M., Laroche, L., Dürr, H.H., \& Syvitski, J.P.M. (2003). Global variability of daily Total Suspended Solids and their fluxes in rivers. Global and Planetary Change, 39, pp. 65-93.

Millward, G. E., Allen, J.I., Morris, A.W., \& Turner, A. (1996). Distributions and fluxes of non-detrital particulate $\mathrm{Fe}, \mathrm{Mn}, \mathrm{Cu}, \mathrm{Zn}$ in the Humber coastal zone, U.K., Continental Shelf Research, 16, pp. 967-993.

Nriagu, JO. (1989). A global assessment of natural sources of atmospheric trace metals, Nature, 338, pp. 47-49. 
Pigeot, J., Miramand, P., Guyot, T., Sauriau, P.G., Fichet, D., Le Moine, O., \& Huet, V. (2006). Cadmium pathways in an exploited intertidal ecosystem with chronic cadmium inputs (Marennes-Oleron, Atlantic coast, France), Marine Ecology-Progress Series 307, pp. 101-114.

Ravail-Legrand, B. (1993). Incidences du débit de la Charente sur la capacité biotique du bassin ostréicole de Marennes-Oléron. Univ. Nantes, 171 pp.

Schäfer J., \& Blanc, G. (2002). Relationship between ore deposits in river catchments and geochemistry of suspended particulate matter from six rivers in southwest France, Science of the Total Environment, 298, pp. 103-118.

Schäfer J., Blanc G., Lapaquellerie, Y., Maillet, N., Maneux, E. \& Etcheber, H. (2002). TenYear-Observation of the Gironde Fluvial System: Fluxes of Suspended Matter, Particulate Organic Carbon and Cadmium, Marine Chemistry, 79, pp. 229-242.

Schäfer, J., Blanc, G., Audry, S., Cossa, D. \& Bossy, C. (2006). Mercury in the Lot-Garonne River system (France): Sources, fluxes and anthropogenic component, Applied Geochemistry, 21, pp. 515-527.

Schleichert, U. (1975). Annual variation of the heavy metal contents of suspended sediments in the Rhine River at Koblenz, Deutsche Gewaesserkundliche Mitteilungen 19, pp. 150157.

Soletchnik, P., Le Moine, O., Faury, N., Razet, D., Geairon, P. \& Goulletquer, P. (1999). Mortalité de l'huître Crassostrea gigas dans le Bassin de Marennes-Oléron. Etude de la variabilité spatiale de son environnement et de sa biologie par un système d'information géographique (SIG), Aquat. Living Resour., 12, pp. 131-143.

Soletchnik, P., Huvet, A., Le Moine, O., Razet, D., Geairon, P., Faury, N., Goulletquer, P. \& Boudry, P. (2002). A comparative field study of growth, survival and reproduction of Crassostrea gigas, C. angulata and their hybrids, Aquatic Living Resources, 15, pp. 243-250.

Strady, E., Kervella, S., Blanc, G., Robert, S., Stanisiere, J.Y., Coynel, A. \& Schäfer, J. (2011). Spatial and temporal variations in trace metal concentrations in surface sediments of the Marennes Oléron Bay. Relation to hydrodynamic forcing, Continental Shelf Research, 31, pp. 997-1007.

Vernier, F., Bordenave, P., Chavent, M., Leccia, O. \& Petit, K. (2010). Modelling scenarios of agriculture changes on freshwater uses and water quality at a large watershed scale - the case of the Charente watershed (France), in International congress on environmental modelling and software - International congress on environmental modelling and software, Ottawa : Canada (2010) - http://hal.archivesouvertes.fr/hal-00546884/en/.

Viers, J., Dupré, B. \& Gaillardet, J. (2009). Chemical composition of suspended sediments in World Rivers: New insights from a new database, Science of the Total Environment, 407, pp. 853-868. 


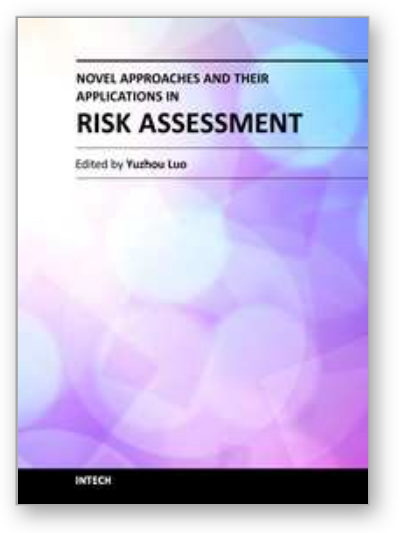

\author{
Novel Approaches and Their Applications in Risk Assessment \\ Edited by Dr. Yuzhou Luo
}

ISBN 978-953-51-0519-0

Hard cover, 344 pages

Publisher InTech

Published online 20, April, 2012

Published in print edition April, 2012

Risk assessment is a critical component in the evaluation and protection of natural or anthropogenic systems. Conventionally, risk assessment is involved with some essential steps such as the identification of problem, risk evaluation, and assessment review. Other novel approaches are also discussed in the book chapters. This book is compiled to communicate the latest information on risk assessment approaches and their effectiveness. Presented materials cover subjects from environmental quality to human health protection.

\title{
How to reference
}

In order to correctly reference this scholarly work, feel free to copy and paste the following:

Coynel Alexandra, Khoury Alaa, Dutruch Lionel, Blanc Gérard, Bossy Cécile, Derriennic Hervé and Schäfer Jörg (2012). Spatial Cadmium Distribution in the Charente Watershed and Potential Risk Assessment for the Marennes Oleron Bay (Southwest France), Novel Approaches and Their Applications in Risk Assessment, Dr. Yuzhou Luo (Ed.), ISBN: 978-953-51-0519-0, InTech, Available from: http://www.intechopen.com/books/novelapproaches-and-their-applications-in-risk-assessment/spatial-cadmium-distribution-in-the-charentewatershed-and-potential-risk-assessment-for-the-marenne

\section{INTECH}

open science | open minds

\section{InTech Europe}

University Campus STeP Ri

Slavka Krautzeka 83/A

51000 Rijeka, Croatia

Phone: +385 (51) 770447

Fax: +385 (51) 686166

www.intechopen.com

\section{InTech China}

Unit 405, Office Block, Hotel Equatorial Shanghai

No.65, Yan An Road (West), Shanghai, 200040, China

中国上海市延安西路65号上海国际贵都大饭店办公楼 405 单元

Phone: +86-21-62489820

Fax: $+86-21-62489821$ 
(C) 2012 The Author(s). Licensee IntechOpen. This is an open access article distributed under the terms of the Creative Commons Attribution 3.0 License, which permits unrestricted use, distribution, and reproduction in any medium, provided the original work is properly cited. 